\title{
Reconstruction of Criminal Policy for Police Personnel who Abused Drugs Based on Justice Value
}

Buala Zega $^{1 *}$, Gunarto $^{2}$, Mahmud Mulyadi ${ }^{3}$

${ }^{1}$ Doctorate Student of Faculty of Law Sultan Agung Islamic University Semarang, Indonesia

${ }^{2}$ Faculty of Law Sultan Agung Islamic University Semarang, Indonesia

${ }^{3}$ Faculty of Law North Sumatra University Medan, Indonesia

DOI: $10.36348 /$ sijlcj.2022.v05i01.005

| Received: 17.12.2021 | Accepted: 21.01.2022 | Published: 24.01.2022

*Corresponding author: Buala Zega

Doctorate Student of Faculty of Law Sultan Agung Islamic University Semarang, Indonesia

\section{Abstract}

The background of this research is to find the weaknesses of the current Criminal Policy for Police Personnel Who Abused Drugs and how to Reconstruct the Criminal Policy For Police Personnel Who Abused Drugs Based On Justice Value. This research is a normative-legal type of research that is used to examine the function of a norm that lays the law as an instrument that regulates and controls society. The approach used in this research is conceptual, a statute approach, a philosophical approach, and a comparative approach. The analysis used in this research is descriptive-qualitative. The results show that Police officers who are suspected of using narcotics and subjected to the investigation must still be considered innocent until proven through a court decision that has permanent legal force (the principle of presumption of innocence) as stipulated in Article 8 paragraph (1) of Law no. 48 of 2009 concerning Judicial Power. However, in reality, the enforcement of the police professional code of ethics against members of the police who are entangled in criminal cases of narcotics abuse has not been carried out properly as the police still do not immediately take firm action against members who are entangled in criminal cases of narcotics abuse, it is impressed that the police are still protecting their members and are considered after the members have been tried in general court and were found guilty of committing a narcotic crime. The police should be able to monitor their members more and instill a higher law-abiding attitude so that their members can avoid criminal acts of drug abuse, such as urine tests. For those who have the authority to prosecute violations of the code of ethics committed by members of the police, they should be more strict in taking action against police who are caught in narcotics use cases and should be rehabilitated as soon as possible, not fired or imprisoned.

Keywords: Reconstruction, Criminal Policy, Rehabilitation, Justice Value.

Copyright () 2022 The Author(s): This is an open-access article distributed under the terms of the Creative Commons Attribution 4.0 International License (CC BY-NC 4.0) which permits unrestricted use, distribution, and reproduction in any medium for non-commercial use provided the original author and source are credited.

\section{INTRODUCTION}

Narcotic addicts according to the law, on one hand, are perpetrators of criminal acts of narcotics abuse namely by the existence of criminal provisions in the narcotics law which regulates imprisonment given to perpetrators of narcotics abuse, but on the other hand, it can be said that according to the narcotics law, the narcotic addict is a victim, as indicated by the provision that narcotics addicts can be sentenced to rehabilitation.

This means that the law still considers narcotic addicts as both perpetrators of criminal acts, and the victim of their own narcotics abuse. Narcotics abuse in criminology literature is considered a victimless crime where the victim and the perpetrator are both the same, in the sense that the victim is the perpetrator and the perpetrator is the victim. This naming refers to the nature of the crime, namely the existence of two parties who carry out transactions or relationships but both do not suffer losses to the other party [1].

Various efforts have been made by the police institution in order to minimize and even eliminate drug abuse, however, the abuse is still rampant even within the police itself. Internal control measures, both by the field of supervision (Inspectorate) and the field of Propam (Profession and internal security), both by periodic methods and sudden inspections (Sidak) accompanied by urine tests to all members of the National Police and PNS Polri from the lowest class or rank (NCO) to high-ranking officers (General) which 
Buala Zega et al., Sch Int J Law Crime Justice, Jan, 2022; 5(1): 30-36

are carried out in collaboration with the Provincial National Narcotics Agency (BNNP), as well as efforts to take firm action for members who are proven to be involved in drug abuse through a general judicial process and are aggravated by submitting them to a trial of the Police Professional Code of Ethics which is subject to sanctions. the punishment is up to dismissal or dishonorable discharge from the police service.

In relation to this, Judging from the data on criminal cases handled by the Directorate of Criminal Investigation and the Director of the Narcotics Investigation of the North Sumatra Regional Police of the 2018's cases, there are 2,651 TSK 3,881, in 2019's cases there are 2,733 TSK 3,461 and until February 2020 , the cases are 2,480 TSK 3,155. It can be said that in general cases, Narcotics crime is still quite high in terms of violations that occur every year.

In simple terms, based on the data above, it can be said that there has been an increase in criminal behavior or criminal acts from year to year, especially regarding the crime of narcotics abuse and its modus operandi.

The increase in the number of general crimes is significantly correlated with the intensity of narcotics crimes that occur, even including the modus operandi and the nature of the actions that lead to sadistic and brutal behavior.

In this regard, if it is reviewed in more depth the contents of the provisions of Article 1 of Law Number 35 of 2009 concerning Narcotics which replace and revoke Law Number 22 of 1997 concerning Narcotics, State Gazette of 1997 Number 67, Supplement to the State Gazette Number 3698, and Law No. Law Number 5 of 1997 concerning Psychotropics, State Gazette of 1997 Number 10, Supplement to the State Gazette Number 3671, it will be found at least 3 (three) classifications which include perpetrators of narcotics crimes, namely:

1. Producer, namely the maker or compounder of narcotics against the law (illegal);

2. Dealers, namely individuals or groups of people who directly or indirectly sell, deliver, or conduct transactions to narcotics users and/or users, either in large quantities (porters) or in small quantities (retailers); and

3. Users, namely people who abuse narcotics against the law, including addicts with a high level of narcotic dependence.

The importance of grouping the roles of perpetrators in narcotics crimes is based on factual cases that have been conducted and will be handled by law enforcers in Indonesia, especially in the police ranks. The role of the perpetrator in a narcotics crime will affect or have an impact on his criminal responsibility, namely the severity and or lightness of the sentence to be imposed. Apart from that, for members of the National Police who are proven to have committed narcotics crimes, there are, in fact, exist a special non-penal sanctions or administrative sanctions.

The policy of implementing non-penal and administrative sanctions for members of the National Police is in line and in accordance with the development of legal pluralism. Globalization does not mean the uniformity of the legal system, because each legal system is culturally specific. This means that legal theory and science today should be directed to be globality conscious as well as plurality conscious and sensitive. Thus, the problem of globalization becomes a necessary thing because of the consequences that must be accepted as an era that continues to be dynamic in the direction of development as well as progress [2].

Considering the high number of members of the National Police, which in this case, in the Police of North Sumatra where the author studied who commit criminal acts of narcotics abuse, are very concerning as this problem may cause disturbance in the stability of security and order, law enforcement, as well as protection, shelter, and service to the community in accordance with the main tasks of the Police themselves. Therefore, special attention is needed from the government and the leadership of the National Police to look for causal factors, preventive efforts to minimize violations committed and law enforcement and, providing criminal sanctions (penal policy) and non-penal sanctions against members of the Police who commit criminal acts of narcotics abuse in order to achieve conducive domestic security.

It is hoped that the realization of a professional, moral, and modern Indonesian Police (Polri) Stature. In one of its mission items, it is stated that the Polri mission is to manage professionally, transparently, accountable and modernly all Polri resources to support the operational tasks of the Polri.

On the other hand, in particular, efforts to eradicate drug abuse have not been carried out completely as referred to in Law no. 35 of 2009 concerning Narcotics which has clearly regulated in certain articles regarding the different punishments that must be carried out against the perpetrators of Drug Crimes in accordance with the role they play as Narcotics abusers.

Meanwhile, the implementation of rehabilitation which is the spirit of Law no. 35 of 2009 concerning Narcotics has not been implemented optimally and almost all Narcotics cases submitted by investigators for examination and trial ended with a prison sentence. However, in order to determine a decision against an accused Narcotics abuser to impose a rehabilitation sentence, a Judge must really consider based on the recommendations of the Dependency 
Buala Zega et al., Sch Int J Law Crime Justice, Jan, 2022; 5(1): 30-36

Integrated Assessment Team only those who are obliged to be rehabilitated as stated in Article 54 of Law No. 35 of 2009 concerning Narcotics. This means that those who receive rehabilitation services are narcotics abusers based on the severity of the users and not their position. This problem is what urges the author to study it further in a research with the main problem as follows:

1. What are the weaknesses of the criminal law policy in dealing with Police members who are proven to have abused narcotics?

2. What are the reconstruction should be for the nonpenal policy in dealing with Polri members who are proven to have abused narcotics based on justice value?

\section{METHOD OF RESEARCH}

This type of research is a kind of empirical juridical, or referred by field research that examines the provisions of applicable law and what happens in reality in society [3]. Juridical empirical research is legal research on the enactment or implementation of normative legal provisions in action at any particular legal event that occurs in society [4]. This research was conducted using a socio-legal approach: because this research focused on social and legal phenomena in society. The research paradigm used for this research is none other than philosophical assumptions or basic assumptions that are based on the Indonesian nation's perspective on existing legal issues, which is Pancasila.

\section{RESEARCH RESULT AND DISCUSSION \\ 1. Weaknesses Of The Criminal Law Policy In Dealing With Police Members Who Are Proven To Have Abused Narcotics}

The Indonesian National Police (Polri) is an institution tasked with protecting, serving, and protecting the community. The police are also tasked with maintaining the security of all Indonesian jurisdictions. The National Police of the Republic of Indonesia (Polri) has a headquarters which is the command center of the Police throughout Indonesia called the National Police Headquarters (Mabes Polri) in Jakarta. The National Police of the Republic of Indonesia has units that are spread throughout the provinces in Indonesia which are responsible or authorized over the jurisdiction of the Province which is called the Regional Police (Polda). One of the units at the Polda level is the North Sumatra Police which is domiciled in Medan (the capital city of North Sumatra Province) located on Sisingamagaraja, Medan. The Directorate of Drug Investigation of the North Sumatra Police has many members. All of these members have their own personalities with each other, of the many members of the North Sumatra Police Narcotics Investigation Directorate, optimal supervision is also needed from the leadership, it is not easy to supervise all members if there is no good cooperation in it. In this case, the leadership has supervised each of its members and even carried out inherent supervision, it is hoped that each member, both in the service environment and in the field, can carry out their duties professionally and not commit deviations that can tarnish the good name of the institution and harm themselves.

Basically, various causal factors can influence an individual to commit a crime. These factors as described above include economic conditions, low education, or because they do not have a fixed source of income or there is a permanent job but the income is not sufficient to meet the costs of daily living needs, as well as a combination of from various things outside of the perpetrators of the crime (the influence of the social environment).

In this regard, the instinct of a person, including members of the National Police, to commit a crime whose consequences are threatened with criminal sanctions is the choice of the perpetrator of the crime, such as because of the element of compulsion. This means that criminal acts committed by the perpetrators, especially in relation to the crime of narcotics abuse, such as the factor of not having a permanent job or sufficient income and so on are irrelevant, especially if the perpetrator is a member of the National Police who has a strong personality and mental attitude (good morals) so as to prevent the misuse of narcotics which is prohibited/threatened with criminal sanctions, as well as the sanctions of the Police Professional Code of Ethics that apply in the internal regulations of the Indonesian National Police.

According to AKBP Juliana Situmorang, SH /Bidkum Polda Sumut [5], the reason some police try narcotics is that when they hang out with their friends, one that doesn't participate in trying to use narcotics are considered less macho (less manly) and by doing their bidding, ultimately they got addicted in contrast to this, Economic factors as a cause are less likely because the Police have a steady income every month, even if there is it is because they want to get a lot of money to have luxury goods or expensive items such as vehicles, cellphones, luxury homes, and others. While the factors from the family; Broken Home and Broken Heart so that they use narcotics as an escape are nothing more than justification.

Stated further that for members of the Police who are still possible to be fostered, they will be given administrative sanctions such as placement in special places and others. However, if the member of the National Police has often violated the law, even become a narcotics dealer, he will provide legal advice and opinions to be dishonorably dismissed through the Code of Ethics trial and the Police Disciplinary Session.

In connection with a crime which is a crystallization of the nature of a person who is evil, which is contrary to the size of the norms and or rules in the environment in which the person or criminal is 
Buala Zega et al., Sch Int J Law Crime Justice, Jan, 2022; 5(1): 30-36

located, then for a Police Member who is involved in a criminal act of narcotics abuse, it will be reasonable to apply criminal sanctions in accordance with the law. with the provisions of Law no. 35 of 2009 concerning Narcotics as well as additional sanctions (non-penal) as regulated in Law no. 2 of 2002 concerning the Indonesian National Police, PP No. 2 Article 12 paragraph 1 of 2003 concerning the dismissal of members of the National Police who commit criminal acts in conjunction with the Regulation of the Head of the State Police of the Republic of Indonesia Number 14 of 2011 concerning the Professional Code of Ethics of the State Police of the Republic of Indonesia which states that:

a. Members of the National Police who are suspected of violating the obligations and/or prohibitions as referred to in Article 6 to Article 16 are declared as Suspected Violators.

b. Alleged violators as referred to in paragraph (1) shall be declared as violators after inspection and obtaining a decision through the KKEP Session.

In relation to the factors that cause a Police Member to commit a criminal act of narcotics abuse, either as a user, dealer, or compounder/producer, it can be said that the dominant factor that plays a role is because the perpetrator is unable to control his or her lust or because there are opportunities as a result of the influence the perpetrator's habit of associating with certain people who are actually the targets of police operations [6]. For example, a member of the National Police who has the status of an intelligence officer or is assigned to the detective department. Because of his duties, the person concerned will always be in contact with people or perpetrators of criminal acts, even in certain cases, such as dismantling mafia network of human trafficking, illegal logging, or narcotics illegal trade which involves various parties and sometimes involving elites or high-ranking officials, the members of the National Police must be able to behave and act like the perpetrators of the crime in question.

If the officer or member of the National Police who carries out the task of undercover as an intelligence officer or a detective officer has a good mental attitude or has a strong personality, then the person concerned can avoid the temptation and influence of dependence on illegal drugs. Likewise, in the context of the crime of trafficking in persons or trafficking for the purpose of exploitation (sex, employing someone by force or by means of persuasion, etc.), or in the crime of illegal logging, the police officers either act as intelligence and detectives must be able to adapt and even sometimes have to live/domicile and associate with the perpetrators of the crime where the place of the crime is concerned.

Through the facts mentioned above, it can be said that the reason a person becomes a criminal is due to heredity or congenital, due to lack of thought or madness, and because of the influence of drinking alcohol or liquor is not proven, except for his opinion which affirms that the factors that cause a person to commit criminal acts, especially those that are intentional, are due to uncontrolled lust and opportunity or the influence of habit.

Based on the facts described above, it can be said that the factors that cause a member of the National Police to use narcotics, among others, are due to the influence of their environment, and the tendency to follow the wrong trend in socializing (following the line and wanting to be considered macho/manly), mental/psychological illness or unstable mind so they are unable to control their passions and resist the temptation to get rich quick. However, it is almost certain that in general, members of the Police who are involved in the abuse of narcotics specifically for users are victims due to the demands of their duties and missions, except for those involved as drug dealers/traffickers. However, members of the National Police who commit a criminal offense or violation of discipline must undergo a process of examination and prosecution both at the trial in the district court and at the professional code of ethics trial as well as the National Police disciplinary hearing with the aim of providing legal certainty to members of the National Police who commit a violation as stated in the Articles described above.

The police are essentially an institution and function of government engaged in the maintenance of public security and order. As an institution or institution, the police have the duties and authorities to maintain public security and order, enforce the law and provide protection, shelter, and service to the community. This police force includes police personnel. Where in carrying out their duties, these police personnel must comply with the norms or rules governing how the attitude should be carried out as police personnel. Each member of the police force has an organizational structure and working procedures for the Indonesian National Police adjusted to the interests of carrying out their duties and authorities which will be further regulated by a Presidential Decree. legislation.

The police law also stipulates that the Indonesian National Police, both on duty at the regional and central levels, have police personnel who abuse narcotics, of course, tarnishing the image of the police as there is an enemy inside the institution who hinder the efforts to eradicate narcotics and illegal drug.

Currently, the government is aggressively fighting drug abuse. Narcotics abuse is transnational in nature because it can cross national borders by using sophisticated modus operandi and technology with a neat management network and supported by an extensive network of organizations and then entering Indonesia as a destination country for illegal narcotics trafficking (point of market state) and has caused many 
Buala Zega et al., Sch Int J Law Crime Justice, Jan, 2022; 5(1): 30-36

victims, especially among the nation's young generation to an alarming level so that it is very dangerous for the life of the community and to the state [7].

Narcotic abuse is a problem that involves all aspects of human life, both physical, biological, psychological, and social.

The impact of drug use and abuse causes more adverse effects for the users themselves and for the surrounding environment. For the users themselves, the use and abuse of drugs can cause conditions such as impaired concentration, memory loss, behavioral deviations, and various other bad consequences. While the social environment, Drug users have an impact on disputes between residents, kinship relations can be tenuous and can even break up or cause social diseases such as sexual deviation, theft, muggings, and so on.

Drug crimes are no longer carried out secretly but have been carried out openly by users and dealers in carrying out the operation of these dangerous goods. Therefore, the government mandates the granting of authority to enforce the law on drug abuse to the National Narcotics Agency and the Indonesian National Police in accordance with Article 81 of the Narcotics Law Number of 2009.

However, in reality, the police that are supposed to carry out their duties as law enforcers to uphold drug abuse law are involved in drug abuse and its enforcement is not running properly. There are many indications that point to police officers abusing narcotics, namely the first indication that police officers use the old way of proving whether it is a narcotic in an indirect way where this can make a police officer addicted. The second indication is that the association of members of the police outside the service has a negative effect on him so that things can happen that harm him by abusing narcotics. The third indication is a police member who hangs out with or knows someone, be it a friend, friend, or family member with the lure of a sum of money or whatever in order to help that person carry out his or her actions, this clearly includes unlawful acts, namely attempts and malicious conspiracy to commit acts. narcotics crime is threatened with the same punishment in accordance with the provisions stipulated in the articles in the Narcotics Law. Police members who also back up the activities of drug syndicates, distribute and use drugs have violated the police professional code of ethics. The police professional code of ethics applies to the police and police functions. The code of ethics for the police profession is not only based on the need for professionalism but has also been regulated normatively in the Republic of Indonesia Law Number 2 of 2002 concerning the Police which was followed up by the Chief of Police Regulation Number 7 of 2006 concerning the Code of Ethics for the Police Profession. There are members of the Indonesian National Police and the Indonesian National Armed Forces who are involved as dealers and users of these narcotics. In fact, they are expected to be able to set an example for the community to stay away from narcotics, considering that members of the Indonesian National Police and the Indonesian National Army are identical with an institution that is very obedient and disciplined to the existing law [8].

\section{The Reconstruction For The Non-Penal Policy In Dealing With Polri Members Who Are Proven To Have Abused Narcotics Based On Justice Value}

The current legal provisions stipulate that members of the police who are involved in criminal acts and are being processed in court to have their status temporarily suspended from work and can also be fired if they cannot be maintained in their jobs.

Police officers who abuse illegal drugs in addition to being imposed with criminal sanctions contained in the Narcotics Law are also subject to sanctions by the relevant agencies which are called administrative sanctions. In accordance with article 13 letter $b$ which explains the main task of the Indonesian National Police, in the name of enforcing the law, all police officers are required to carry out investigations into all forms of criminal acts. If it is the police officers themselves who violate a provision that is included in a criminal act, then this is not in accordance with the main duties of the Indonesian National Police, because the National Police should be the role model for Indonesian citizens in enforcing applicable laws and regulations.

The law applies to anyone who violates it without exception for police officers so that apart from being imposed the sanctions contained in the Narcotics Law, administrative sanctions are also imposed for officers who violate them from their respective agencies. If the police are proven to have committed a narcotics crime, according to Prosecutor Didit Koko Prastowo [9], the person must still be punished. The application of laws other than the Narcotics Law, the process in trying them refers to the Criminal Procedure Code which can be studied in the provisions of the Police Law. There are several sanctions that can be imposed on the police, namely:

a. Subjected to Police Regulations;

b. Taken to a professional court or disciplinary hearing, which then the threat of punishment is imposed according to the decision of the trial itself;

c. Disrespectful dismissal (PTDH);

d. Demotion.

Sanctions or punishments given by the competent agency to police officers who are proven to have abused narcotics must be firm. Thus, it is hoped that it can create a sense of deterrent for them to commit narcotics crimes. There must be a special policy in dealing with this, not only sanctions in the form of 
Buala Zega et al., Sch Int J Law Crime Justice, Jan, 2022; 5(1): 30-36

dismissal but also imposed with criminal sanctions in accordance with applicable regulations. There are certain reasons for the suspects of narcotics abuse to increase their sentences because the actions carried out are classified as very dangerous to the interests of the community.

Members of the National Police of the Republic of Indonesia are subject to the power of the general court in accordance with Article 29 of the Police Law. Therefore, it can be interpreted that Polri members are civilians and are not subject to military law.

However, for members of the National Police, the Code of Professional Ethics and Disciplinary Regulations are applied even though they are civilians as contained in Government Regulation Number 2 of 2003 concerning Disciplinary Regulations for Members of the Indonesian National Police and the provisions regarding the Police Professional Code of Ethics are contained in PERKAP Number 14 of 2011 concerning the Code of Professional Ethics of the Indonesian National Police.

Criminal acts committed by members of the police, such as narcotics abuse, are subject to administrative and criminal sanctions.

Proved guilty or not, police officers must still carry out trials in terms of the code of ethics regulated in PERKAP Number 14 of 2011. Police officers who abuse illegal drugs have deviated from the regulations regarding discipline and code of ethics in accordance with those contained in Article 5 letter a Government Regulation No. 2 of 2003 Jo. Article 6 and Article 7 of PERKAP Number 14 of 2011, all police officers are required to maintain the rule of law and also protect the honor, reputation, and dignity of the Police. Police professional ethics is the crystallization of Tribata values which are based on and interpreted by Pancasila which describes the attitude of all police officers. which includes state ethics, institutional ethics, community ethics, and personal ethics, which are then included in the Code of Professional Ethics of the Indonesian National Police [10].

Accuracy is needed in the preparation of police ethics because it is the foundation of police ethics. Previously, Tribata gave identity to the National Police regarding the drafting of law regarding the Indonesian National Police. Then it turns into a code of ethics. Acts that violate the rules of the code of ethics and discipline will be investigated and if they are guilty they can be punished.

The imposition of disciplinary sanctions as well as sanctions for violating the code of ethics does not have an effect on criminal prosecution for police officers who are found to have violated narcotics crimes as described in Article 12 paragraph 1 of Government Regulation No. 2 of 2003 Jo. Article 28 paragraph 2 of PERKAP Number 14 of 2011. Thus, police officers who abuse illegal drugs will undergo criminal procedural legal processes even though sanctions for violating the code of ethics and disciplinary sanctions have been imposed.

In addition, police officers who are suspected of abusing illegal drugs are currently under investigation and are considered innocent until a decision is made or what is called the presumption of innocence as regulated in Article 8 paragraph 1 of Law Number 48 of 2009 concerning Judicial Power.

Furthermore, he or she will be threatened with dishonorable dismissal in accordance with Article 12 paragraph 1 letter a PP Number 1 of 2003 concerning the Dismissal of Members of the Indonesian National Police if the criminal decision has been rendered. Members of the National Police will be dishonorably discharged from the police service if they are proven guilty based on a court decision that has permanent legal force based on the considerations of the competent authorities and cannot be granted waivers in order to remain in the National Police service.

The dismissal is carried out after passing the trial period at the Commission for the Professional Code of Ethics of the Indonesian National Police which is described in Article 12 paragraph 2 PP Number 1 of 2003. So even though the police officers are civilians, it can be seen from the differences in the process of investigating cases by other citizens because Police members are also bound by disciplinary rules and a code of ethics that must also be obeyed, as well as being subject to the laws and regulations [11].

The process of enforcing the code of ethics of the police profession against members of the police who are caught in a criminal case of narcotics abuse will be examined and if proven they will be subject to sanctions. The imposition of disciplinary sanctions and sanctions for violations of the code of ethics does not remove the criminal charges against the police officers concerned. Police officers who use narcotics will still be prosecuted even though they have undergone disciplinary sanctions and sanctions for violating the code of ethics. Police officers who are suspected of using narcotics and subjected to the investigation must still be considered innocent until proven through a court decision that has permanent legal force (the principle of presumption of innocence) as stipulated in Article 8 paragraph (1) of Law no. 48 of 2009 concerning Judicial Power.

However, in reality, the enforcement of the police professional code of ethics against members of the police who are entangled in criminal cases of narcotics abuse has not been carried out properly where 
Buala Zega et al., Sch Int J Law Crime Justice, Jan, 2022; 5(1): 30-36

the police do not immediately take firm action against members who are entangled in criminal cases of narcotics abuse, it is impressed that the police are still protecting their members and are considered after the members have been tried in general court and were found guilty of committing a narcotic crime. Members of the police who are involved in criminal acts and are being processed in court are usually temporarily suspended in their work and can also be fired if they cannot be maintained in their jobs anymore.

Police officers who abuse illegal drugs in addition to being imposed with criminal sanctions contained in the Narcotics Law are also subject to sanctions by the relevant agencies which are called administrative sanctions. In accordance with article 13 letter $\mathrm{b}$ which explains the main task of the Indonesian National Police, namely, to enforce the law, all police officers are required to carry out investigations into all forms of criminal acts. If it is the police officers themselves who violate a provision that is included in a criminal act, then this is not in accordance with the main duties of the Indonesian National Police, because the National Police should be the role model for Indonesian citizens in enforcing applicable laws and regulations.

\section{CONCLUSION}

1. Law enforcement by means of a penalty is just one aspect of the community's efforts to tackle crime. Besides that, it is still known that the community's efforts to tackle crime through non-penal means. Non-penal efforts in tackling crime are closely related to penal efforts. This non-penal effort by itself will greatly support the implementation of criminal justice in achieving its goals. Therefore, Prevention and eradication of drug abuse by Police Officer must be carried out with an integral approach, namely between penal and non-penal means.

2. Police investigators tend to process suspected narcotics addicts, abusers, and victims of narcotics abuse to be sentenced to prison rather than rehabilitated. Police officers must carry out a police code of ethics trial, and if proven guilty by being sentenced to a sentence of more than 5 (five) years, then the police officer can be dishonorably dismissed from his office or removed from his position and if the sentence imposed is less than 5 (five) years then the police officer can still be considered, whether only given disciplinary sanctions or being sent to a place or position far from drugs.

\section{REFERENCES}

1. Crowther-Dowey, C. (2007). The Police and Drugs. 10.1007/978-1-137-12445-6_7.

2. Bacon, M. (2016). The Police on Drugs: Police Detectives, Drug Law Enforcement and Proactive Investigation. 10.1093/acprof:oso/9780199687381.003.0005.

3. Faisal. (2010). Menerobos Positivisme Hukum. Rangkang Education, Yogyakarta.

4. Pratama, T. G. W. (2020). The Urgency for Implementing Crytomnesia on Indonesian Copyright Law. Saudi Journal of Humanities and Social Sciences, 5(10), 508-514.

5. Juliana, S. (2021). Interview, In His Position as Legal Field of Regional Police of North Sumatera Regarding Drugs Abuse, Medan, Indonesia.

6. Bacon, M. (2016). Policing the 'Drug Problem': Police Detectives, Drug Law Enforcement and Proactive Investigation. 10.1093/acprof:oso/9780199687381.003.0002.

7. Hayati, U., Maslihah, S., \& Musthofa, M. A. (2020). Stres Kerja pada Polisi. Jurnal Sains Psikologi, 9(2), 96.

8. Rahmawati, D., \& Silvi, R. (2021, November). Pengaruh Faktor Sosial Demografi dan Kinerja Polisi terhadap Kepercayaan Masyarakat kepada Polisi di Indonesia Tahun 2017. In Seminar Nasional Official Statistics (Vol. 2021, No. 1, pp. 661-673).

9. Didit, K. P. (2021). Interview, In His position as Prosecutor Regarding the prosecution process of a police who violated the drugs abuse law, Medan, Indonesia.

10. Widodo, W., Budoyo, S., \& Pratama, T. G. W. (2018). The role of law politics on creating good governance and clean governance for a freecorruption Indonesia in 2030. The Social Sciences, 13(8), 1307-1311.

11. Mast, B. D., Benson, B. L., \& Rasmussen, D. W. (2000). Entrepreneurial police and drug enforcement policy. Public Choice, 104(3), 285308 . 